\title{
Medicolegal
}

\section{Surrogate mothers}

\author{
BY OUR LEGAL CORRESPONDENT
}

Baby Cotton has been exported but loose threads remain. Born on 4 January and made the subject of a place of safety order on the application of the London Borough of Barnet on the same day (under section 28 of the Children and Young Persons Act, 1969), the baby was made a ward of court on 8 January. On 11 January $\mathrm{Mr}$ Justice Latey granted care and control of the baby to the natural father and his wife, and leave was given to take her to their home abroad on their undertaking to return her to the jurisdiction if the court should so order. Unless the couple have assets in England and Wales (or a pressing need to return here from time to time) the undertaking is totally unenforceable. On 14 January in open court the judge gave reasons for his earlier decision. ${ }^{1}$

The judge has given strict orders that no efforts should be made to identify the natural father or publish identifying details. But some facts are contained in his judgment. It appears that evidence was given to establish that the male applicant in the wardship proceedings was the natural father. The child is apparently relieved of some of the difficulties which might arise if a putative father was encouraged in the belief that he was the father when in fact he was not-when both the rules of inheritance and nationality would be in issue.

\section{Parents}

The judge said that the father and his wife were both in their 30 s and had been married for some years. The father was fertile, but the wife had a congenital defect which prevented her from having a child. The nationality of the couple was not stated. In 1983 the man had paid an agency in the United States which had undertaken to find a surrogate mother in England. In 1984 the father had come to England to provide semen, with which the surrogate mother was inseminated by a nurse. In a television interview (Independent Television News, 15 January) the surrogate mother claimed that insemination was successful at the second attempt. She voluntarily relinquished her parental rights (for reward) and left the baby in hospital some hours after the birth and had not seen her since.

All that mattered for the court was what was best for the baby and not how she had arrived. The judge rejected any suggestion that the father and his wife were unsuitable as parents because they had entered into the arrangements. The natural father and his wife were both highly qualified professional people with a house in the country and another in town. Materially they could give the baby a very good upbringing, but much more important, said the judge, they were excellently equipped to meet the emotional needs of the baby. They were warm, caring, sensible, and highly intelligent and would be able to answer the baby's questions when the time came.

The form of registration of the birth has not been disclosed, and having regard to the judge's order cannot be published. One can only speculate. When the child wants to apply for a passport, or to apply for a civil service job, the full facts will probably have to be explained to her.

Presumably, having been born outside the country where she will be brought up, her claim to nationality of that country will depend on proof of her natural father's paternity by complex blood tests. In the event of her assumed parents dying intestate she would in most legal systems probably have the status of an illegitimate child in relation to her assumed father and no status at all in relation to her assumed mother. These problems might be resolved by adoption, but if the purpose of the original transaction is adoption the money consideration raises issues of illegality.

Despite the many problems ahead the baby's life abroad may be better than if she had been taken into care and adopted in England. If the court had been able to consider any interest other than the interest of the baby it might have determined that the quickest way of stopping this trade was to refuse to allow the baby to leave the country.

Even so, the commercial side of the transaction is in shoal waters. The American head of the agency which organised the contract is reported as expressing doubts about paying the promised $£ 6500$ to the surrogate mother. ${ }^{2}$ One of the matters worrying the agency is the larger amount of money (reportedly $£ 20000$ ) received by the surrogate mother from a newspaper for her story (Daily Star). Any action to recover the promised fee might fail on the ground that the contract was contrary to public interest.

It is said that a Bill is to be promoted to prevent such commercial transactions. To be effective such a Bill would have to provide for forfeiture of any fee paid both by the putative patents and by the press, television, or other agencies.

There are no reports of any emotional problems in the Cotton family. But a concerned liberal newspaper has published the story of a surrogate mother "who has concealed her identity under the pseudonym Kirsty Stevens" in a story under her full facial photograph. ${ }^{3}$ Kirsty Stevens conceived, apparently, not by artificial insemination but by the same method as Hagar in the Old Testament. As with Hagar, there have been some difficulties of interpersonal emotional relationships. ${ }^{4}$

\section{References \\ 1 Anonymous. Natural father given custody of ward and leave to take her abroad. The Times 1985 Jan 15:8(cols 6-8). \\ 2 Anonymous. Kim Cotton "may not be paid her fee." Daily Telegraph 1985:1(col 8). \\ 3 Dally E. New surrogate mother tells all. Observer 1985 Jan 13:1(cols 4-8), 9(cols 1-8), 11(cols 1-3). 4 Holy Bible. Genesis xvi, 1-16.}

\section{Does ranitidine have an adverse effect on a pregnant woman or her fetus?}

There is no evidence that ranitidine has any harmful effects on the mother or the fetus if used during pregnancy, and it is not teratogenic in animals. Experience with the use of ranitidine in pregnancy, however, is limited. The manufacturer has reports of only seven women who took ranitidine during pregnancy; no adverse effects were seen (personal communication). Ranitidine is excreted into breast milk, and concentrations exceed those in maternal serum. ${ }^{1}$ There is, however, no reason to believe that it would harm the baby.- LINDA BEELEY, consultant clinical pharmacologist, Birmingham.

1 Riley AJ, Crowley P, Harrison C. Transfer of ranitidine to biological fluids: milk and serum. In: Misiewicz JJ, Wormstey KG, eds. The clivical use of renitidine. Oxford: Medicine Publishing Foundation; 1982:77-86. (Medicine Publishing Foundation series 5.) 